\title{
Anti-inflammatory activities of Olea europaea extracts from Jeju Island on LPS-induced RAW 264.7 cells
}

\author{
Min-Jin Kim ${ }^{1}$, Juyeong Lee ${ }^{2}$, Sang Suk Kim ${ }^{3}, \mathrm{Ki}$ Cheol Seong ${ }^{4}$, Chan Kyu Lim ${ }^{4}$, \\ Kyung Jin Park ${ }^{3}$, Hyun Joo $\mathrm{An}^{3}$, Young Hun Choi ${ }^{3}$, \\ Seung-Young Kim ${ }^{5}$, Chang-Gu Hyun ${ }^{2 *}$ \\ ${ }^{1}$ Nakdonggang National Institute of Biological Resources, Sangju 37242, Korea \\ ${ }^{2}$ Department of Chemistry and Cosmetics, Jeju National University, Jeju 63243, Korea \\ ${ }^{3}$ Citrus Research Institute, National Institute of Horticulture and Herbal Science, Jeju 63243, Korea \\ ${ }^{4}$ Agricultural Research Institute for Climate Change, National Institute of Horticulture and Herbal Science, Jeju 63243, Korea \\ ${ }^{5}$ Department of Pharmaceutical Engineering and Biotechnology, Sunmoon University, Asan 31460, Korea
}

\section{LPS 자극 RAW 264.7 세포에서 제주산 올리브 추출물의 항염 활성}

\author{
김민진 ${ }^{1} \cdot$ 이주영 ${ }^{2} \cdot$ 김상숙 $^{3} \cdot$ 성기철 $^{4} \cdot$ 임찬규 $^{4} \cdot$ 박경진 $^{3} \cdot$ 안현주 $^{3} \cdot$ 최영훈 $^{3} \cdot$ 김승영 $^{5} \cdot$ 현창구 $^{2 *}$ \\ ${ }^{1}$ 국립낙동강생물자원관, ${ }^{2}$ 제주대학교 화학 · 코스메틱스학과, \\ ${ }^{3}$ 농촌진흥청 국립원예특작과학원 감귤연구소, ${ }^{4}$ 농촌진흥청 국립원예특작과학원 온난화대응농업연구소, \\ ${ }^{5}$ 선문대학교 제약생명공학과
}

\begin{abstract}
Lipopolysaccharide (LPS)-induced activation of murine RAW 264.7 cells results in the production of pro-inflammatory cytokines including $\mathrm{PGE}_{2}, \mathrm{IL}-6$, TNF- $a$, and IL-1 $\beta$. In this study, we investigated the anti-inflammatory effects of the Olea europaea extract from Jeju island using LPS which induces an inflammatory response. To examine the potential anti-inflammatory properties of the Olea europaea extract, we measured the amount of nitric oxide (NO), prostaglandin $\mathrm{E}_{2}\left(\mathrm{PGE}_{2}\right)$, tumor necrosis factor-alpha (TNF- $\alpha$ ), interleukin-6 (IL-6), and IL-1 $\beta$ on RAW 264.7 cells after the Olea europaea extract treatment. The Olea europaea extracts showed higher anti-inflammatory activity by inhibiting the production of PGE $_{2}$, NO, TNF- $a$, IL-6, and IL-1 $\beta$ induced by LPS stimulation in RAW 264.7 cells. Also, Olea europaea extracts decreased mRNA expression of iNOS, and COX-2. There was no cytotoxicity in the macrophage proliferation treated with the Olea europaea extract compared to the control in the LDH assay. These results suggest that the Olea europaea extract may exert significant effects on inflammatory factors and be a potential source as a new natural anti-inflammatory agent. Further investigations will focus on cell-based in vitro assays and in chemically identifying the major active components mediating the anti-aging and anti-inflammation responses.
\end{abstract}

Key words : Olea europaea, anti-inflammatory, prostaglandin $\mathrm{E}_{2}$, interleukin, nitric oxide

\section{서 론}

*Corresponding author. E-mail : cghyun@jejunu.ac.kr

Phone : 82-64-754-3542, Fax : 82-64-756-3561

Received 30 May 2018; Revised 25 July 2018; Accepted 6 August 2018.

Copyright (c) The Korean Society of Food Preservation. All rights reserved.
생체 내에서는 에너지 생산을 위해 산화과정 중에 상당 량의 활성산소들이 생성된다. 활성산소가 순간적으로 다량 발생되거나 만성적으로 활성산소가 발생하게 되면 세포 구성성분과 강하게 반응하여 세포와 조직에 손상을 가하 고, 지속적인 손상은 DNA 변성, 지질 산화, 단백질 분해 등을 초래하게 된다(1). 자유 라디칼은 다양한 화학 물질에 의해 생성되며 여러 대사 과정으로 인해 세포의 죽음과 조직 손상을 유도한다. 따라서, 유기체는 다양한 방어 시스 
템과 글루타티온과 같은 항산화 물질을 사용하여 상대적으 로 낮은 농도의 자유 라디칼을 유지해야한다(2). 흔히 항산 화 화합물로 불리는 폴리페놀은 직접적인 항산화 작용은 할 수 없지만, 다양한 세포 및 분자과정을 조절하기 위해 표적 단백질과 상호 작용하여 건강을 지키는데 중요한 역할 을 하며 최근 암과 같은 질병으로부터 보호하는 능력이 있다고 보고되었다 $(3,4)$.

염증은 감염 및 상해에 대한 반응으로 tumor necrosis factor-alpha(TNF-a)와 interleukin-6(IL-6)를 비롯한 다양한 전 염증성 cytokine을 생성한다. 또한 cyclooxygenase (COX-2)와 iNOS(inducible nitric oxide synthase)에 의해 합 성 된 prostaglandin $\mathrm{E}_{2}\left(\mathrm{PGE}_{2}\right)$ 와 nitric oxide( $\left.\mathrm{NO}\right)$ 는 염증 반 응을 매개하는 것으로 알려져 있다. 만약, 통제하지 않고 방치하면 염증 매개체는 많은 염증성 질환의 발병 기전에 관여하게 된다(5). Lipopolysaccharide(LPS)는 다양한 염증 성 사이토카인을 방출하기 위해 대식세포를 자극하는 잘 알려진 염증 리간드 중의 하나이며, 이러한 염증성 사이토 카인은 감염 후 숙주 생존에 필수적이며 조직 손상 복구에 도 필요하다(6). 대식세포는 유해 물질에 대한 숙주 방어에 중요한 역할을 하며 자가 면역 질환, 감염 및 염증 질환을 포함한 다양한 질병 과정에 관여하며(7), 다양한 염증 매개 체가 많은 염증 관련 인간 질환의 병인에 관여하고 있다고 알려져 있다(8,9). 그러므로 대식세포에서 LPS에 의해 유도 된 전 염증성 cytokine의 발현 감소는 발병과 관련하여 질병 을 예방하는데 유용하다.

현대사회가 발달됨에 따라 효과적인 염증 치료제의 개발 이 지속적으로 이루어 졌지만 현대 약물 요법에는 신뢰할 수 없는 약물이 아직 많아 약물 대신 사용할 수 있는 천연물 이 필요한 실정이다(10). 올리브 나무(Olea europaea)는 물 푸레나무과(Oleaceae)의 상록교목으로 성경에서 최초의 식 물로 언급할 정도로 예로부터(BC 3,000년경) 재배되어 왔 다(11). 약용식품으로 이용되는 올리브 잎의 임상 효능들은 주로 고열, 말라리아, 고압, 아테롬성 동맥경화증, 결장암, 염증, 식중독 등의 증상에 효능이 있으며 최근에는 $\mathrm{AIDS}$ 에 도 효능이 있는 것으로 알려져 있다(12-14). 현재 올리브가 건강상에 미치는 이점에 대한 관심이 높아짐으로 인해 세계 의 여러 국가 및 지역에서도 재배되고 있으며 올리브유의 원료, 향신료나 약용식품으로 현재까지 이용되고 있다 $(11,15,16)$. 올리브 잎의 주요 생리활성 성분들은 페놀성 화합물들로 hydroxytyrosol, tyrosol, catechin, caffeic acid, vanillic acid, $p$-coumaric acid, diosmetin, vanillin, rutin (17-20), oleuropein, demethyloleuropein, oleuroside, verbascoside, ligstroside, flavonoid glycosides 등이 있다(21-23). 특히 이들 성분 중에서 폴리페놀과에 속하는 oleuropein은 올리브 잎 에 가장 많이 함유되어 있으며, 최근 생리활성 연구가 활발 하게 이루어지고 있다(17,19). 또한 이러한 폴리페놀은 과 산화에 대해 특별한 저항성이 있다고 알려져 있어 동맥성
심장 질환의 주요 원인인 LDL 콜레스테롤 축적 및 지질 산화를 억제에도 도움을 준다고 알려져 있다(24). 이 외의 연구로는 올리브 잎 추출물의 anti-HIV 활성(25), 건조조건 에 따른 올리브 잎의 화학성분의 변화 등이 있지만 올리브 의 항염증 활성을 연구한 것은 부족한 실정이다(26). 따라서 본 연구에서는 제주에서 처음으로 아열대 과수인 올리브를 노지 재배하는 데 성공한 올리브 열매와 가지 추출물을 murine macrophage cell line인 Raw 264.7 세포에 처리하여 $\mathrm{NO}$ 생성 억제활성, $\mathrm{PGE}_{2}$, 전염증성 cytokines(TNF-a, $\mathrm{IL}-6$, IL-13) 생성 억제 활성과 염증성 단백질 발현에 미치는 영향 을 분자생물학적으로 분석하여 항염증 활성에 어떠한 영향 을 미치는지 연구하였다.

\section{재료 및 방법}

\section{올리브 추출물 제조}

본 연구에 사용된 올리브는 2016년 제주도에서 채집하 여, 부위별(잎과 줄기)로 나누어 충분히 건조시킨 후 분쇄하 였다. 올리브 잎과 가지는 $80 \%$ 에탄올 용매를 첨가하여 24 시간 실온에서 침출하였고, 여과 후 감압농축기를 사용 하여 농축하였다. 올리브 잎과 가지 추출물의 수율은 각각 $25.6 \%$ 와 $19.5 \%$ 로 올리브 잎 추출물의 수율이 가지 추출물 에 비해 약 1.3 배 정도 높게 측정되었다. 올리브 부위별 추출물은 phosphate buffer saline(PBS)에 용해하여 실험에 사용하였다.

\section{세포 배양}

Murine macrophage cell line인 RAW 264.7 cell을 American Type Culture Collection(ATCC, Manassas, VA, USA)로 부터 분양 받아 $10 \%$ fetal bovine serum(FBS)와 100 units/mL penicillin-streptomycin이 함유된 Dulbecco's Modified Eagle Medium(DMEM, Gibco, Grand Island, NY, USA) 배지를 사용하여 $37^{\circ} \mathrm{C}, 5 \% \mathrm{CO}_{2}$ incubator에서 3 일 간격으로 계대 배양을 실시하였다.

\section{세포 독성 측정}

올리브 추출물이 세포의 성장에 미치는 영향을 측정하기 위하여 LDH assay를 이용하여 실험하였다. RAW 264.7 세 포 $\left(3.0 \times 10^{5}\right)$ 를 $10 \% \mathrm{FBS}$ 가 첨가된 $\mathrm{DMEM}$ 배지를 이용하여 24 well plate에 분주한 후 24시간 동안 배양한 후 시료와 $\mathrm{LPS}(1 \mathrm{\mu g} / \mathrm{mL})$ 를 동시 처리하고 24시간 동안 배양하였다. 이후 배양 배지를 $3,000 \mathrm{rpm}$ 에서 5 분간 원심 분리하여 $\mathrm{LDH}$ cytotoxicity detection kit(Promega, Madison, WI, USA)를 이용하여 측정하였다. 96-well plate에 원심 분리하여 얻은 배양 배지 $50 \mu \mathrm{L}$ 와 reconstitude substrate mix $50 \mu \mathrm{L}$ 를 넣고, 실온에서 빛 차단하여 반응 시켰다. 반응 후 $50 \mu \mathrm{L}$ 의 stop 
solution을 넣고 microplate reader(Bio-TEK instrument Inc., Vermont, WI, USA)를 사용하여 $490 \mathrm{~nm}$ 에서 흡광도를 측정 하였다. 각 시료군에 대한 흡광도 값을 구하였으며, 대조군 의 흡광도 값과 비교하여 독성 정도를 평가하였다.

\section{Nitric oxide(NO) 생성 억제 활성 측정}

$\mathrm{RAW} 264.7$ 세포$\left(3.0 \times 10^{5}\right)$ 를 $10 \% \mathrm{FBS}$ 가 첨가된 $\mathrm{DMEM}$ 배지를 이용하여 24-well plate에 분주한 후 24시간 동안 배양한 후 시료와 LPS $(1 \mu \mathrm{g} / \mathrm{mL})$ 를 동시 처리하고 24시간 동안 배양하였다. 생성된 NO는 Griess 시약을 이용하여 세포 배양액 중에 존재하는 $\mathrm{NO}_{2}^{-}$의 형태로 측정하였다(27). 세포배양 상등액 $100 \mu \mathrm{L}$ 와 Griess 시약 $100 \mu \mathrm{L}$ 를 혼합하여 96-well plate에서 10분간 실온암소로 반응시킨 후 microplate reader(Bio-TEK instrument Inc.)를 사용하여 540 $\mathrm{nm}$ 에서 흡광도를 측정하였다. 표준농도 곡선은 sodium nitrite $\left(\mathrm{NaNO}_{2}\right)$ 를 serial dilution하여 얻었다.

\section{Prostaglandin $\mathrm{E}_{2}\left(\mathrm{PGE}_{2}\right)$ 생성 억제 활성 측정}

$\mathrm{RAW} 264.7$ 세포 $\left(3.0 \times 10^{5}\right)$ 를 $10 \% \mathrm{FBS}$ 가 첨가된 $\mathrm{DMEM}$ 배지를 이용하여 24-well plate에 분주한 후 24시간 동안 배양하였다. 이후 배지를 제거하고 농도별로 조제된 시료 와 $\mathrm{LPS}(1 \mu \mathrm{g} / \mathrm{mL})$ 를 함유한 배지를 동시에 처리하여 24시간 배양하였다. 24시간 후 배양 배지를 원심분리(12,000 rpm, $3 \mathrm{~min}$ )하여 얻어진 상층액의 $\mathrm{PGE}_{2}$ 함량을 측정하였다. 모든 시료는 정량 전까지 냉동보관 $\left(-20^{\circ} \mathrm{C}\right)$ 하였고, PGE2는 mouse enzyme-linked immunosorbent assay(ELISA) kit(R\&D Systems Inc., Minneapolis, MN, USA)를 이용하여 정량 하였 으며 standard에 대한 표준곡선의 $\mathrm{R}^{2}$ 값은 0.99 이상이었다.

전염증성 cytokines(TNF-a, IL-6, IL-1ß) 생성 억제 활성 측정

RAW 264.7 세포 $\left(3.0 \times 10^{5}\right)$ 를 $10 \%$ FBS가 첨가된 DMEM 배지를 이용하여 24-well plate에 분주한 후 24시간 동안 배양하였다. 이후 배지를 제거하고 농도별로 조제된 시료 와 $\mathrm{LPS}(1 \mu \mathrm{g} / \mathrm{mL})$ 를 함유한 배지를 동시에 처리하여 24시간 배양하였다. 24 시간 후 배양 배지를 원심분리 $(12,000 \mathrm{rpm}$, $3 \mathrm{~min}$ )하여 얻어진 상층액의 전염증성 cytokine 함량을 측정 하였다. 모든 시료는 정량 전까지 냉동보관 $\left(-20^{\circ} \mathrm{C}\right)$ 하였다. 전염증성 cytokine은 mouse enzyme-linked immunosorbent assay(ELISA) kit(R\&D Systems Inc.)를 이용하여 정량 하였 으며 standard에 대한 표준곡선의 $\mathrm{R}^{2}$ 값은 0.99 이상이었다.

\section{Western blot analysis}

RAW 264.7 세포 $\left(3.0 \times 10^{5}\right)$ 를 $10 \%$ FBS가 첨가된 DMEM 배지를 이용하여 6-well plate에 분주한 후 24시간 동안 배양 하였다. 이후 배지를 제거하고 농도 별로 조제된 시료와 $\mathrm{LPS}(1 \mathrm{\mu g} / \mathrm{mL})$ 를 함유한 배지를 동시에 처리하여 24시간
배양하였다. 이후 세포를 PBS로 2회 세척하고 lysis buffer[ $1 \times$ RIPA(Upstate Cell Signaling Solution, Lake Placid, NY, USA), $1 \mathrm{mM}$ pheylmethylsulfonyl fluoride(PMSF), 1 $\mathrm{mM} \mathrm{Na} \mathrm{VO}_{4}, 1 \mathrm{mM} \mathrm{NaF}, 1 \mu \mathrm{g} / \mathrm{mL}$ aprotinin, $1 \mathrm{\mu g} / \mathrm{mL}$ pepstain, and $1 \mathrm{\mu g} / \mathrm{mL}$ leupeptin]를 이용해 1시간 동안 lysis 시킨 후 원심분리 $(15,000 \mathrm{rpm}, 15 \mathrm{~min})$ 하여 단백질 상등액 만 분리하였다. 단백질 농도는 bovine serum albumin(BSA) 를 표준으로 Bio-Rad protein assay regent(Bio-Rad Laboratories, Inc., Hercules, CA, USA)를 사용하여 정량 하 였다. 정량한 단백질을 $10 \%$ 의 polyacrylamaide gel에 전기 영동하고 Poly-vinylidene difluoride(PVDF) membrane (Millipore, Billerica, MA, USA)에 $200 \mathrm{~mA}, 2$ 시간 동안 전이 시켰다. 단백질이 전이된 membrane을 $5 \%$ 탈지분유를 포함 한 $0.05 \%$ Tween20/Tris-buffered saline( $0.05 \% \mathrm{~T} / \mathrm{TBS})$ 에 넣 고 상온에서 blocking 시킨 후, 1 차 항체와 반응시켰다. 1 차 항체 반응은 iNOS antibody(1:5,000, Calbiochem, San Diego, CA, USA), COX-2 antibody(1:1,000, BD Biosciences Pharmingen, San Diego, CA, USA), $\beta$-actin antibody (1:10,000, Sigma-Aldrich, St. Louis, MO, USA)를 이용하여 $4^{\circ} \mathrm{C}$ 에서 24 시간 반응시켰다. 1 차 항체 반응이 끝난 membrane은 $0.05 \% \mathrm{~T}-\mathrm{TBS}$ 로 10 분씩 4 회 세척한 다음 2 차 항체(Jackson ImmunoResearch, West Grove, PA, USA)를 $1: 5,000$ 또는 $1: 10,000$ 으로 희석하여 상온에서 1 시간 반응 한 뒤 $0.05 \% \mathrm{~T}-\mathrm{TBS}$ 로 20 분씩 3 회 세척하였다. 단백질은 Enhanced chemiluminescance(ECL) 방법을 이용하여 imaging densitometer(model GS-700, Bio-Rad Laboratories, Inc.)를 통해 측정하였다.

\section{통계처리}

모든 실험은 3회 반복하여 측정하였고, 그 결과는 평균값 \pm 표준편차로 나타냈으며 통계적 분석은 SPSS 10.0 프로그 램을 이용하여 각 처리구 간의 유의성 $(\mathrm{p}<0.05,0.01)$ 을 검증 을 위해 분산분석(analysis of variance, ANOVA)후 tukey test로 다중비교를 실시하였다.

\section{결과 및 고찰}

\section{올리브 추출물의 세포 독성 측정}

RAW 264.7 세포에 올리브 각 부위별(잎, 가지) 추출물 $(200,400,800 \mu \mathrm{g} / \mathrm{mL})$ 과 LPS $(1 \mu \mathrm{g} / \mathrm{mL})$ 를 동시 처리하여 24 시간 배양한 후 $\mathrm{LDH}$ 분석법을 이용하여 세포 생존률을 확인하였다. Fig. 1 에서 보는 것과 같이, 올리브 부위별 추출 물의 $\mathrm{LDH}$ 활성은 모든 농도에서 올리브 추출물 미처리군 과 비교할 경우 $0 \%$ 이하의 활성을 나타내는 것으로 보아 유의적인 차이가 없음을 확인하였다. 세포막이 손상되거나 괴사가 일어나면 원형질 및 핵 내에 $\mathrm{LDH}$ 활성이 증가되고, 
세포 밖으로 유출되어 배양배지 내의 $\mathrm{LDH}$ 활성이 증가되 는 것으로 알려져 있다(16). 따라서 NO 생성 억제 활성과 $\mathrm{PGE}_{2}$, 전염증성 cytokine 생성 억제 활성 연구는 $800 \mu \mathrm{g} / \mathrm{mL}$ 의 농도까지 실험을 진행하였다.

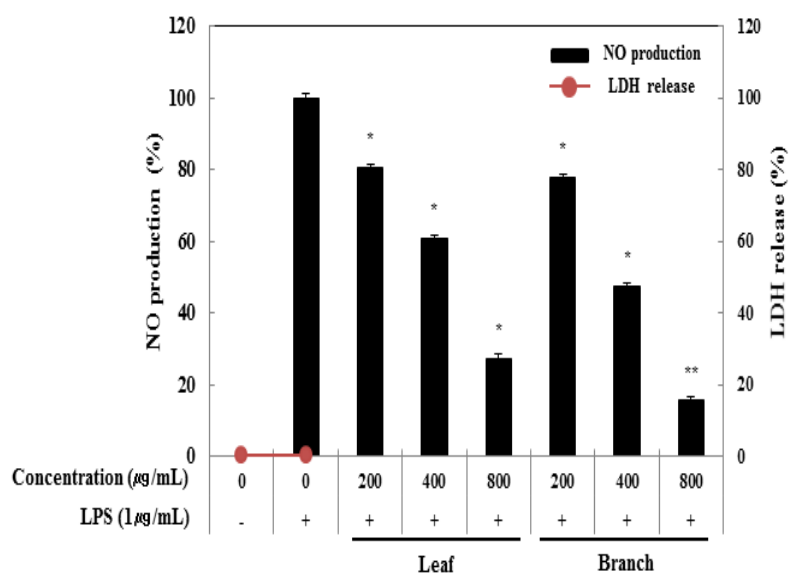

Fig. 1. Inhibitory effects of Olea europaea extract on nitric oxide production in RAW 264.7 cells.

The production of nitric oxide was assayed in the culture medium of cells stimulated with LPS $(1 \mu \mathrm{g} / \mathrm{mL})$ for $24 \mathrm{~h}$ in the presence of Olea europaea extract $(200,400$, and $800 \mu \mathrm{g} / \mathrm{mL}$ ). Cytotoxicity was determined by LDH assay.

Data represent the means \pm SD with three separate experiments. One-way ANOVA was used for comparisons of multiple group means followed by t-test (significant as compared to control. $\left.{ }^{*} \mathrm{p}<0.05 ;{ }^{* *} \mathrm{p}<0.01\right)$.

\section{올리브 추출물의 nitric oxide(NO) 생성 억제 활성}

본 연구에서는 활성산소 중 하나이며 염증 유발에 중요 한 역할을 한다고 알려진 nitric oxide(NO)의 생성에 올리브 추출물이 어떤 영향을 미치는지 알아보았다. RAW 264.7 세포에 올리브 각 부위별(잎, 가지) 추출물 $(200,400,800$ $\mu \mathrm{g} / \mathrm{mL})$ 과 LPS $(1 \mu \mathrm{g} / \mathrm{mL})$ 를 동시 처리하여 24시간 배양하였 다. 배양 후 생성된 $\mathrm{NO}$ 의 양은 Griess 시약을 이용하여 세포 배양액에 존재하는 $\mathrm{NO}_{2}{ }^{-}$의 형태로 측정하였다. 측정 한 결과, LPS 단독 처리군은 NO의 생성을 유도하였고, LPS 단독 처리군과 비교했을 때 잎과 가지 추출물은 $200 \mu \mathrm{g} / \mathrm{mL}$ 농도에서 각각 $19.5 \%, 22.2 \%$ 로 NO 생성을 억제하였으며 최고 농도인 $800 \mu \mathrm{g} / \mathrm{mL}$ 에서는 각각 $72.7 \%, 84.4 \%$ 로 억제하 는 것으로 나타나 가지 추출물이 잎 추출물보다 강한 NO 생성 억제 활성이 있는 것으로 생각된다(Fig. 1).

\section{Prostaglandin $\mathrm{E}_{2}\left(\mathrm{PGE}_{2}\right)$ 생성 억제 활성}

Nitric oxide(NO) 생성 억제 활성 측정과 동일한 조건으로 $\mathrm{PGE}_{2}$ ELISA kit를 이용하여 $\mathrm{PGE}_{2}$ 생성 억제 활성을 측정한 결과, 잎과 가지 추출물은 LPS 단독 처리군과 비교했을 때, 각각의 처리 농도에서 $\mathrm{PGE}_{2}$ 의 생성에 농도 의존적으로 억제 효과가 있는 것을 확인할 수 있었다(Fig. 2). 최고 농도 인 $800 \mathrm{\mu g} / \mathrm{mL}$ 농도에서는 잎과 가지 추출물의 활성이 각각 $95.2 \%$ 와 $96.2 \%$ 로 나타나 올리브 잎과 가지 추출물 모두 PGE2 생성을 효과적으로 억제하는 것으로 나타냈다.

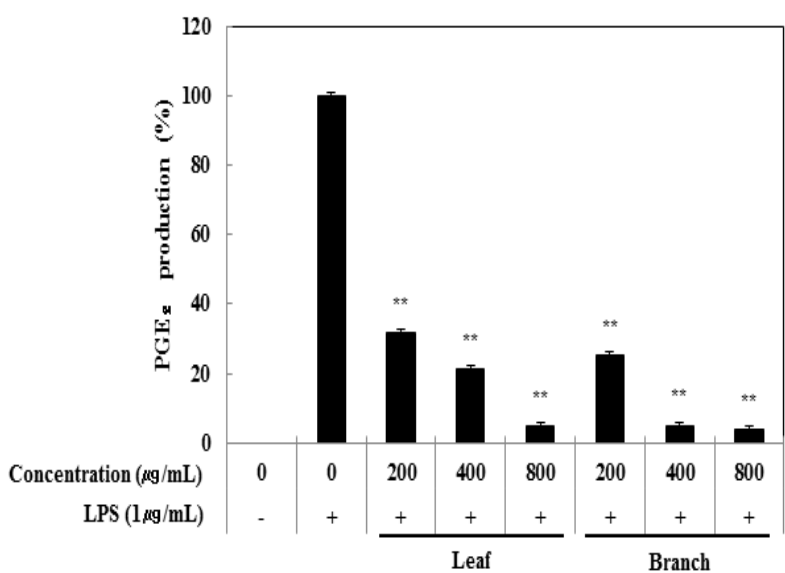

Fig. 2. Inhibitory effects of Olea europaea extract on PGE2 production in RAW 264.7cells.

The production of $\mathrm{PGE}_{2}$ was assayed in the culture medium of cells stimulated with LPS $(1 \mu \mathrm{g} / \mathrm{mL})$ for $24 \mathrm{~h}$ in the presence of Olea europaea extract (200, 400, and $800 \mu \mathrm{g} / \mathrm{mL})$.

Data represent the means $\pm S D$ with three separate experiments. One-way ANOVA was used for comparisons of multiple group means followed by t-test (significant as compared to control. ${ }^{*} \mathrm{p}<0.05 ;{ }^{* *} \mathrm{p}<0.01$ ).

전염증성 cytokines(TNF-a, IL-6, IL-1ß) 생성 억제 활성

Cytokine은 면역세포가 분비하는 단백질로서 면역세포 의 활성, 증식 및 분화를 조절하여 염증반응을 매개하는 인자이다. 염증성 질환의 원인과 치료를 규명하기 위하여 cytokine의 역할은 매우 중요하며, TNF- $a$, IL-1 $\beta$ 및 IL-6은 in vitro 및 in vivo 모두에서 염증반응을 조절하는 물질로 대표적인 pro-inflammatory cytokine으로 알려져 있다(15). RAW 264.7 세포에서 올리브 각 부위별(잎, 가지) 추출물이 전염증성 cytokine인 TNF-a, $\mathrm{IL}-6$ 및 $\mathrm{LL}-1 \beta$ 의 발현에 미치는

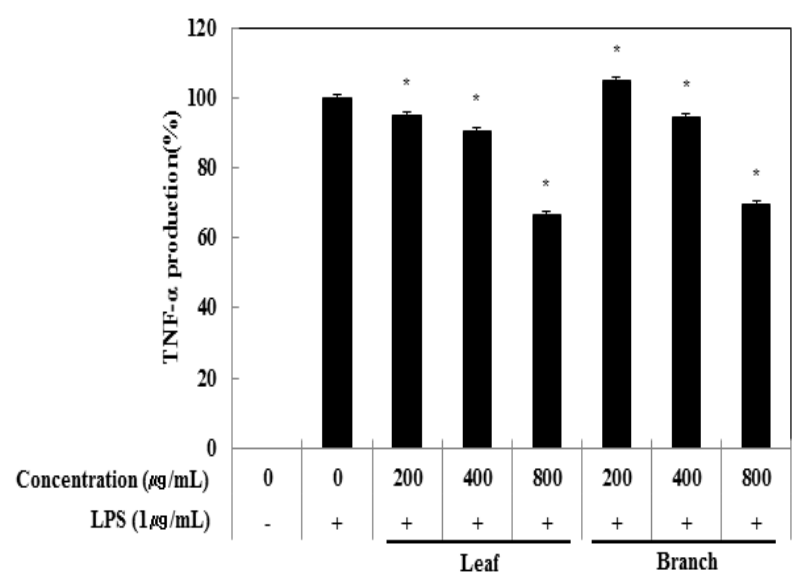

Fig. 3. Inhibitory effects of Olea europaea extract on TNF-a production in RAW 264.7 cells.

The production of TNF- $a$ was assayed in the culture medium of cells stimulated with LPS $(1 \mu \mathrm{g} / \mathrm{mL})$ for $24 \mathrm{~h}$ in the presence of Olea europaea extract $(200,400$, and $800 \mu \mathrm{g} / \mathrm{mL})$.

The data represent the means $\pm \mathrm{SD}$ with three separate experiments (significant as compared to control. ${ }^{*} \mathrm{p}<0.05$ ). 


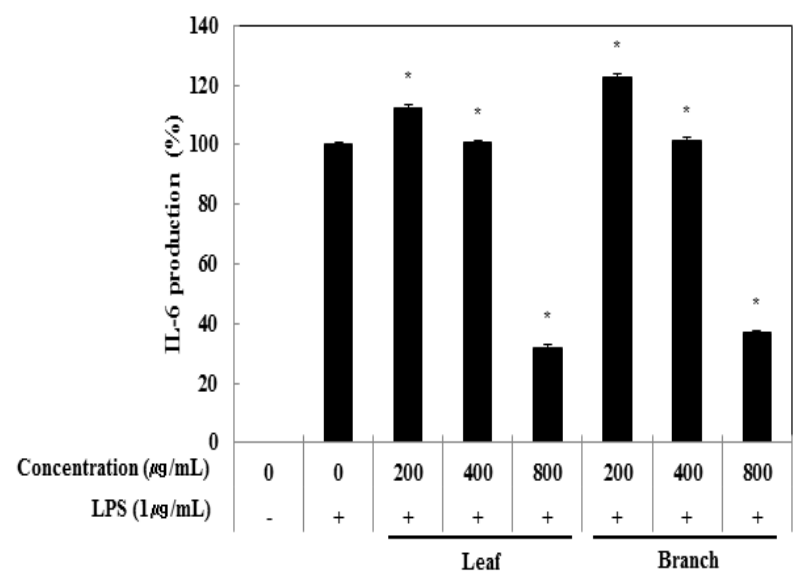

Fig. 4. Inhibitory effects of Olea europaea extract on IL-6 production in RAW 264.7 cells.

The production of IL-1 $\beta$ was assayed in the culture medium of cells stimulated with LPS $(1 \mu \mathrm{g} / \mathrm{mL})$ for $24 \mathrm{~h}$ in the presence of Olea europaea extract (200, 400, and $800 \mu \mathrm{g} / \mathrm{mL})$.

The data represent the means $\pm \mathrm{SD}$ with three separate experiments (significant as compared to control. $\left.{ }^{*} \mathrm{p}<0.05\right)$

영향을 ELISA kit를 이용하여 조사하였다. 올리브 각 부위 별(잎, 가지) 추출물 $(200,400,800 \mu \mathrm{g} / \mathrm{mL})$ 과 LPS $(1 \mu \mathrm{g} / \mathrm{mL})$ 를 동시 처리하여 24시간 배양한 후 TNF- $a$ 의 생성 억제 활성을 확인한 결과 LPS 단독 처리군과 비교했을 때 잎과 가지 추출물 모두 농도 의존적으로 TNF-a의 생성을 억제 시키는 것으로 확인되었으며 최고 농도인 $800 \mu \mathrm{g} / \mathrm{mL}$ 에서 올리브 잎 추출물의 억제 활성이 $33.6 \%$, 가지 추출물의 억제 활성이 $30.5 \%$ 로 나타났다(Fig. 3). 다음으로 IL-6 생성 억제 활성을 측정한 결과, $\mathrm{IL}-6$ 의 생성 억제 활성은 800 $\mu \mathrm{g} / \mathrm{mL}$ 에서 잎과 가지 추출물은 $68.0 \%, 63.2 \%$ 의 활성이 나

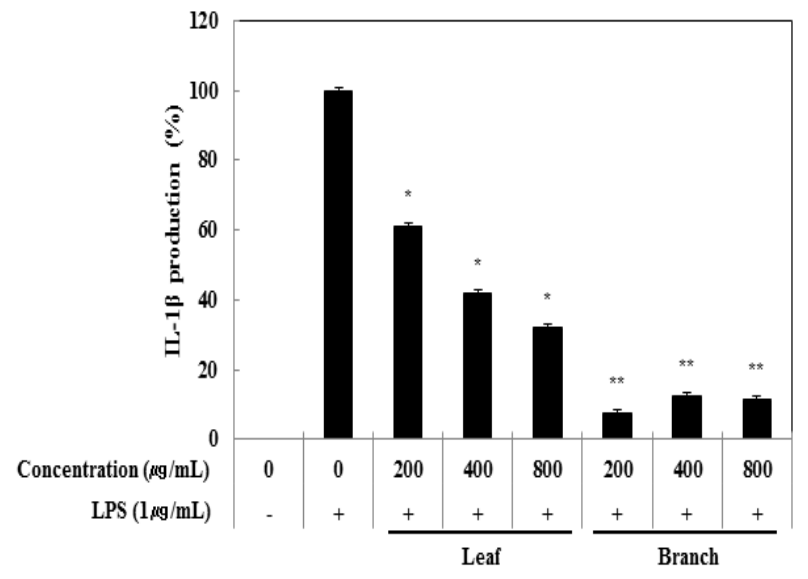

Fig. 5. Inhibitory effects of Olea europaea extract on IL-1 $\beta$ production in RAW 264.7 cells.

The production of IL-1 $\beta$ was assayed in the culture medium of cells stimulated with LPS $(1 \mu \mathrm{g} / \mathrm{mL})$ for $24 \mathrm{~h}$ in the presence of Olea europaea extract $(200,400$, and $800 \mu \mathrm{g} / \mathrm{mL}$ ).

Data represent the means \pm SD with three separate experiments. One-way ANOVA was used for comparisons of multiple group means followed by $\mathrm{t}$-test (significant as compared to control. ${ }^{*} \mathrm{p}<0.05 ;{ }^{*} \mathrm{p}<0.01$ )
타나 IL-6 생성 억제에 효과가 있는 것으로 확인되었다(Fig. 4). 또한, $\mathrm{IL}-1 \beta$ 의 발현에 미치는 영향을 조사한 결과, 올리 브 잎 추출물은 농도 의존적으로 IL-1 $\beta$ 생성 억제하는 것을 확인할 수 있었으나, 가지 추출물은 $200 \mathrm{\mu g} / \mathrm{mL}$ 에서부터 뚜렷하게 $\mathrm{IL}-1 \beta$ 생성을 억제하는 것으로 관찰되었다(Fig. 5).

\section{Western blot을 통한 iNOS 및 COX-2 단백질 발현 억제 효과 측정}

염증상태에서 iNOS에 의해 생성된 NO는 혈관투과성, 부종 등의 염증반응을 촉진시킬 뿐만 아니라 염증매개체의 생합성을 촉진하며, macrophage에서 LPS나 cytokine에 의 해 염증성 매개물질들이 과잉 생산되는 중요한 메카니즘이 된다(28). 또한, $\mathrm{COX}$ 는 arachidonic acid를 $\mathrm{PGE}_{2}$ 로 전환시 키는 효소로 COX-1은 정상적인 생체기능에 작용하며, 많 은 염증 억제 약물들의 작용기전은 prostaglandin 합성 억제 를 나타내는데 이러한 메카니즘은 COX-2의 생성 및 활성 저해에 의한 것으로 알려져 있다(29,30). 따라서 올리브 부 위별(잎, 가지) 추출물의 iNOS 및 COX-2의 단백질 발현에 미치는 영향을 알아보기 위해 western blot 방법을 이용하여 iNOS 및 COX-2 단백질의 발현량을 조사하였다. Fig. 6과 같이 LPS 처리로 인해 iNOS 단백질의 발현이 증가하였고, 올리브 부위별 추출물을 농도별로 처리 하였을 때 $200 \mu$ $\mathrm{g} / \mathrm{mL}$ 에서부터 유의적으로 억제되는 것을 확인 할 수 있었 다. 반면, 염증반응에서 중요한 역할을 하는 $\mathrm{COX}-2$ 단백질 발현량을 확인한 결과 $\mathrm{COX}-2$ 의 발현의 변화가 거의 없었 다.

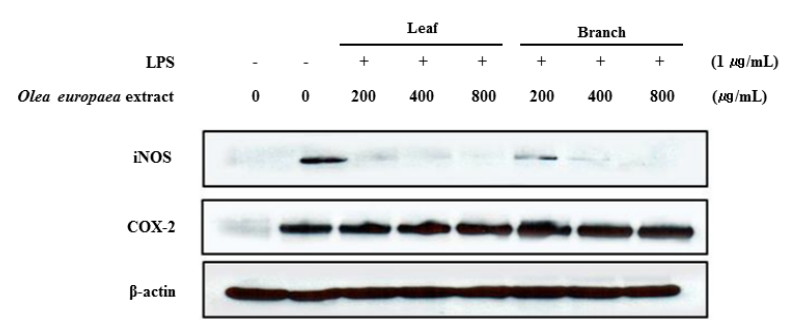

Fig. 6. Inhibitory effects of Olea europaea extract on the protein level of iNOS and COX-2 expression in LPS-stimulated RAW 264.7 cells.

Cells $\left(1.0 \times 10^{6}\right.$ cells $\left./ \mathrm{mL}\right)$ were pre-incubated for $18 \mathrm{~h}$, and then treated with LPS $(1$ $\mu \mathrm{g} / \mathrm{mL}$ ) and Sample for $24 \mathrm{~h}$. The protein levels of iNOS, COX-2 were analyzed by Western blot.

\section{요 약}

본 연구는 LPS로 유도된 RAW 264.7 세포에서 다양한 약용식품으로 사용되고 있는 올리브 잎과 가지 추출물의 항염증 효과를 확인하였다. 올리브 잎과 가지 추출물은 각 각 RAW 264.7 세포에 대하여 세포독성을 나타내지 않았고, 
LPS 자극에 의한 $\mathrm{NO}$ 및 $\mathrm{PGE}_{2}$ 생성을 농도 의존적으로 억제했다. 또한, 올리브 추출물은 LPS 자극으로 분비된 TNF- $a, \mathrm{IL}-1 \beta$ 및 $\mathrm{IL}-6$ 의 전염증성 cytokine의 분비량을 억제 하였으며, 특히 $200 \mathrm{\mu g} / \mathrm{mL}$ 농도에서 올리브 가지 추출물이 잎 추출물 보다 IL-6를 억제하는 것으로 나타났다. 대표적 인 염증 관련 신호 전달 경로 인자인 iNOS 및 COX-2의 발현을 검토한 결과 올리브 추출물은 $\mathrm{iNOS}$ 의 발현을 농도 의존적으로 현저히 감소시키는 것으로 관찰되었으나, 각각 의 올리브 추출물이 COX-2 발현에는 영향을 미치지 않은 것으로 관찰되었다. 이와 같은 결과는 올리브 각 부위별 추출물은 모두 $\mathrm{NOS}$ 및 NO 조절 경로를 조절하는 것으로 사료되나 iNOS 및 COX-2 단백질 발현은 병립적이지 않을 수 있음을 제시하고 있다. 본 연구 결과로 올리브 추출물이 독성과 부작용이 적은 항염증 효능을 가진 기능성 화장품 소재로써 개발 가능성이 있다고 사료된다.

\section{감사의 글}

이 논문은 농촌진흥청 연구사업(세부과제번호: PJ010934082015) 의 지원을 받아 수행된 연구입니다.

\section{References}

1. Fang YZ, Yang S, Wu G (2002) Free radicals, antioxidants, and nutrition. Nutrition, 18, 872-879

2. Bhattacharyya A, Chattopadhyay R, Mitra S, Crowe SE (2014) Oxidative stress: an essential factor in the pathogenesis of gastrointestinal mucosal diseases. Physiol Rev, 94, 329-354

3. Rodriguez ML, Estrela JM, Ortega AL (2013) Natural polyphenols and apoptosis induction in cancer therapy. J Carcinog Mutagen, S6, 1-10

4. Saibandith B, Spencer JPE, Rowland IR, Commane DM (2017) Olive Polyphenols and the Metabolic Syndrome. Molecules, 22, 1082-1095

5. Ritchlin CT, Haas-Smith SA, Li P, Hicks DG, Schwarz EM (2003) Mechanisms of TNF- $a-$ and RANKLmediated osteoclastogenesis and bone resorption in psoriatic arthritis. J Clin Invest, 111, 821-831

6. Becker S, Mundandhara S, Devlin RB, Madden M (2005) Regulation of cytokine production in human alveolar macrophages and airway epithelial cells in response to ambient air pollution particles: further mechanistic studies. Toxicol Appl Pharmacol, 207, S269-S275

7. Pierce GF (1990) Macrophages: important physiologic and pathologic sources of polypeptide growth factors. Am J Respir Cell Mol Biol, 2, 233-234

8. Simons RK, Junger WG, Loomis WH, Hoyt DB (1996) Acute lung injury in endotoxemic rats is associated with sustained circulating IL-6 levels and intrapulmonary cinc activity and neutrophil recruitment - role of circulating TNF- $a$ and IL- $\beta$ ?. Shock, 6, 39-45

9. Guslandi M (1998) Nitric oxide and inflammatory bowel disease. Eur J Clin Invest, 28, 904-907

10. Hiraganahalli D, Chandrasekaran C, Dethe S, Mundkinajeddu D, Pandre MK, Balachandran J, Agarwal A (2012) Hepatoprotective and antioxidant activity of standardized herbal extracts. Pharmacogn Mag, 8, $116-123$

11. Gucci R, Lombardini L, Tattini M (1997) Analysis of leaf water relations in leaves of two olive (Olea europea) cultivars differing in tolerance to salinity. Tree physiol, 17, 13-21

12. Zarzuelo A, Duarte J, Jimenez J, Gonzalez M, Utrilla MP (1991) Vasoliator effect of olive leaf. Planta Med, 57, 417-419

13. Hertog MGL, Feskens EJM, Hollman CH, Katan MB, Kromhout D (1993) Dietary antioxidant flavonoids and risk of coronary heart disease. Lancet, 342, 1007-1011

14. Aziz NH, Farag SE, Mousa LA, Abo-Zaid MA (1998) Comparative antibacterial and antifungal effects of some phenolic compounds. Microbios, 93, 43-54

15. Fernandez-Escobar R, Moreno R, Garcia-Creus M (1999) Seasonal changes of mineral nutrients in olive leaves during the alternate-bearing cycle. Sci Hortic, 82, 25-45

16. Delgado-Pertinez M, Gomez-Cabrera A, Garrido A (2000) Predicting the nutritive value of the olive leaf (Olea europea): digestibility and chemical composition and in vitro studies. Anim Feed Sci Technol, 87, 187-201

17. Bianco A, Uccella N (2000) Biophenolic components of olives. Food Res Int, 33, 475-485

18. Tasioula-Margari M, Okogeri O (2001) Isolation and characterization of virgin olive oil phenolic components by HPLC/UV and GC-MS. J Food Sci, 66, 530-534

19. Ryan D, Antolovich M, Prenzler P, Robards K, Lavee S (2002) Biotransfomations of phenolic compounds in Olea europaea L.. Sci Hortic, 92, 147-176.

20. Silva S, Gomes L, Leitao F, Coelho AV, Vilas Boas L (2006) Phenolic compounds and antioxidant activity of Olea europaea L. fruits and leaves. Food Sci Technol Int, 12, 385-395

21. Nino AD, Lombardo N, Perri E, Procopio A, Raffaelli 
A, Sindora G (1997) Direct identification of phenolic glucosides from olive leaf extracts by atmospheric pressure Ionization tandem mass spectrometry. J Mass Spectrom, 32, 533-541

22. Visioli F, Poli A, Galli C (2002) Antioxidant and other biological activities of phenols from olives and olive oil. Med Res Rev, 22, 65-75

23. Del-Rio JA, Baidez AG, Botia JM, Ortuno A (2003) Enhancement of phenolic compounds in olive plants (Olea europaea L.) and their influence on resistance against Phytophthora sp.. Food Chem, 83, 75-78

24. Espin JC, Soler-Rivas C, Wichers HJ (2000) Characterization of the total free radical scavenger capacity of vegetable oils and oil fractions using 2, 2-diphenyl-1-picrylhydrazyl radical. J Agric Food Chem, $48,648-656$

25. Lee-Huang S, Zhang L, Huang PL, Chang YT, Huang PL (2003) Anti-Hiv activity of olive leaf extract (OLE) and modulation of host cell gene expression by HIV-1 infection and OLE treatment. Biochem Biophys Res Commun, 307, 1029-1037
26. Delgado-Pertinez M, Gomez-Cabrera A, Garrido A (2000) Predicting the nutritive value of the olive leaf (Olea europaea): digestibility and chemical composition and in vitro studies. Anim Feed Sci Technol, 87, 187-201

27. Lee ST, Jeong YR, Ha MH, Kim SH, Byun MW, Jo SK (2000) Induction of nitric oxide and TNF-a by herbal plant extracts in mouse macrophages. J Korean Soc Food Sci Nutr, 29, 342-348

28. Noh KH, Jang JH, Min KH, Chinzoring R, Lee MO, Song YS (2011) Suppressive effect of green tea seed coat ethly acetate fraction on inflammation and its mechanism in RAW 264.7 macrophage cell. J Korean Soc Food Sci Nutr, 40, 625-634

29. Rocca B, FitzGerald GA (2002) Cyclooxygenases and prostaglandins: shaping up the immune response. Int Immunopharmacol, 2, 603-630

30. Turini ME, DuBois RN (2002) Cyclooxygenase-2: a therapeutic target. Annu Rev Med, 53, 35-57 